\title{
Curcumin and its derivatives in breast cancer: Current developments and potential for the treatment of drug-resistant cancers
}

Belinda J. Cridge ${ }^{1}$, Lesley Larsen ${ }^{2}$ and Rhonda J. Rosengren ${ }^{1 *}$

*Correspondence: rhonda.rosengren@otago.ac.nz

'Pharmacology and Toxicology Department, University of Otago, New Zealand.

${ }^{2}$ Department of Chemistry, University of Otago, New Zealand.

\begin{abstract}
Curcumin, a spice found in curry powder, is receiving considerable attention as a possible chemopreventative and chemotherapeutic. This review considers the evidence for the use of curcumin as a treatment for breast cancer, particularly triple negative breast cancers (lacking ER, PR and HER2) which are resistant to many current treatments. Evidence suggests that curcumin suppresses the growth of breast cancers both in vitro and in vivo. In ER-cell lines curcumin causes apoptosis via a range of mechanisms at concentrations ranging between $1 \mu \mathrm{M}$ and $7.6 \mu \mathrm{M}$ depending on the cell line and system. In xenograft models, curcumin has been shown to be effective but is limited by its bioavailability. This can be improved by nanotechnologies such as micelles. Studies with micelles have shown that these systems increase the uptake and cytotoxicity of curcumin in vitro. In xenotransplantation models micelles improved bioavailability and increased the half-life of curcumin while showing increases in apoptosis in implanted tumours. The last area discussed is the development of curcumin derivatives. Many of these show increased cytotoxicity (less than $1 \mu \mathrm{M}$ ) and improved pharmacokinetic profiles in vivo. The most potent of these compounds developed to date are RL66 and RL71 with $\mathrm{IC}_{50}$ values less than $1 \mu \mathrm{M}$ across a range of breast cancer cell lines, decreased metastasis in a xenograft model, decreased angiogenesis markers and improved tumour growth inhibition as compared to curcumin. Overall, this review concludes that curcumin and its derivatives show future potential as a powerful broad-spectrum treatment for breast cancer.
\end{abstract}

Keywords: Curcumin, breast cancer, nanotechnology, micelle, derivatives, chemotherapeutic, triple negative breast cancer

\section{Introduction}

Curcumin is derived from the spice turmeric (or curry powder) and has long been used to enhance the flavour of food. It has been demonstrated to have a wide range of cellular effects including chemopreventative and chemotherapeutic properties. Over the past five years this has led to a deluge of information on the mechanism by which curcumin acts. However, curcumin is poorly absorbed through the gastrointestinal tract. Therefore, a number of laboratories around the world are looking to increase the clinical efficacy of curcumin through chemical modification or through nanotechnology delivery systems. This review focusses specifically on the potential of curcumin and its derivatives as chemotherapeutics for breast cancer. The triple negative subset of breast cancers that do not respond well to current treatments will be afforded particular focus.

\section{Breast cancer}

Breast cancer is recognized as being heterogeneous in terms of its biological and clinical behaviour. Historically breast cancers have been classified by histological grade. The most common subtypes are reported as invasive ductal carcinoma not otherwise specified (IDS NOS), with 75\% prevalence and invasive lobular carcinoma (ILC) with $10 \%$ prevalence [1]. With the development of rapid immunohistological screening techniques, classification by receptor status has also become common. Tumour profiling by the presence or absence of the oestrogen (ER), progesterone (PR) and human epidermal growth factor receptor 2 (HER2) are now routinely performed. Unfortunately, receptor status correlates poorly with histological grading and so both techniques are widely utilized to guide clinical decision making [2]. In general, ER+ tumours respond best to available therapeutics and have the highest survival rates whereas triple negative cancers, lacking ER, PR and HER2, remain resistant to current treatment options and have the worst prognosis [3]. Further developments in experimental techniques allow researchers to type cancers based on DNA, RNA and microRNA markers but many of these classifications are prohibitively expensive and so are not immediately relevant to the clinical setting [1,4-7].

\section{Triple negative breast cancers}

Triple negative breast cancers (TNBCs) account for approximately $10-17 \%$ of all breast cancers [8]. Clinically, they are more prevalent in young women and there is some evidence of increased prevalence in African-American women [3]. TNBCs are poorly differentiated, highly malignant, more aggressive and have a poor outcome [9]. They are also characterized by high rate of early recurrence and visceral metastasis [10]. The molecular changes associated with TNBCs include $p 53$ mutation, overexpression of Ki67 and EGFR, and dysfunction in the BRCA1 pathway [11]. It is estimated that EGFR is expressed in $60 \%$ of TNBCs [12]. In addition, TNBCs have an over expression of 
Cridge et al. Oncology Discovery 2013,

http://www.hoajonline.com/journals/pdf/2052-6199-1-6.pdf

doi: 10.7243/2052-6199-1-6

Table 1. Therapeutic targets and investigational agents for triple-negative breast cancer [14-16].

\begin{tabular}{ll}
\hline Target mechanism & $\begin{array}{l}\text { Existing Therapeutic } \\
\text { Options }\end{array}$ \\
\hline Targeting aberrant DNA repair & $\begin{array}{l}\text { PARP inhibitors } \\
\text { DNA transcription inhibitors } \\
\text { Platinum agents }\end{array}$ \\
Inhibition of microtubule function & Taxanes \\
Inducing release of Reactive & Doxorubicin \\
Oxygen Species (ROS) & Cisplatin \\
Anti-angiogenic agents & Bevacizumab \\
& Sunitinib \\
EGFR targeting & Cetuximab \\
& Erlotinib \\
Epigenetic modifications & Trichostatin A \\
& Butyrate \\
c-Kit targeted & Vorinostat \\
Src inhibitor & Imatinib \\
mTOR inhibitor & Dasatinib \\
\hline
\end{tabular}

Table 2. Molecular targets of anticancer activity of curcumin in cancer cells [18].

\begin{tabular}{|c|c|}
\hline Pathway & Target \\
\hline Cytokines & $\begin{array}{l}\text { Decreased: IL-1; IL-2; IL-5; IL-6; IL-8; IL-12; } \\
\text { IL18; MCP; MIP; MaIP; TNFa }\end{array}$ \\
\hline $\begin{array}{l}\text { Growth Factors and } \\
\text { receptors }\end{array}$ & $\begin{array}{l}\text { Decreased: VEGF*; } \beta \text {-FGF*; HER; CTGF; FGF; } \\
\text { HGF; TF; NGF; EGF; PDGF; TGF- } \beta 1 \\
\text { Receptors: } \\
\text { Decreased: ER- } \alpha \text {; HER-2; AR; EGRF; Fas-R; IR; } \\
\text { EPCR; H2R; CXCR4; IL-8R; LDLR; ITR; AHR } \\
\text { Increased: DR-5 }\end{array}$ \\
\hline $\begin{array}{l}\text { Metastasis, angiogenesis } \\
\text { and invasion }\end{array}$ & $\begin{array}{l}\text { Decreased: MMP-2*; MMP- } 3^{*} \text {; MMP-9*; RON- } \\
\text { TKR }{ }^{*} \text { Integrin a (6) } \beta(4)^{*} \text { : LAR }{ }^{*} \text { CXCL1, } 2^{*} \text {; } \\
\text { ICAM-1; ELAM-1; IAP-1, VCAM-1; uPA } \\
\text { Increased: TIMP-1,2* }\end{array}$ \\
\hline Apoptosis molecules & $\begin{array}{l}\text { Decreased: } \mathrm{Bcl}-2 ; \mathrm{Bcl}-\mathrm{XL}^{*} \\
\text { Increased: } \mathrm{Bax}^{*} \text {; } \mathrm{Bad}^{*} ; \mathrm{P} 21^{*} ; \mathrm{P} 27^{*} \text {; mapsin*; } \\
\text { P53; Caspase activation }{ }^{*} \text { Depolymerization of } \\
\text { mitotic microtubules* }\end{array}$ \\
\hline Cell cycle proteins & $\begin{array}{l}\text { Decreased: Cyclin D1; GSK3 b; E-Cadherin*; } \\
\text { Cyclin E }\end{array}$ \\
\hline Transcription factors & $\begin{array}{l}\text { Decreased: NFkB*; HIF- }{ }^{*} \text {; Notch-1; EGR-1; } \\
\text { WT-1; } \beta \text {-catenin }{ }^{*} \text {; AP-1; STAT-1; STAT-3; } \\
\text { STAT-4; STAT-5 CREB-BP } \\
\text { Increased: Nrf-2; PPAR- } \gamma \text {; ERE }\end{array}$ \\
\hline Enzymes & $\begin{array}{l}\text { Decreased: COX-2*; GST; DNA pol; } \\
\text { Telomerase; TMMP-3; Src-2; FPT; ODC; } \\
\text { PhP-D; iNOS; NQO-1; 5-LOX; GICL; ATPase; } \\
\text { ATFase; GCL; AATF-1 } \\
\text { Kinases: } \\
\text { Decreased: MAPK; ERFR-K; ERK; JAK; PAK; } \\
\text { PKA; PKB; PTK; PhK; IL-1R AK; Pp60c-tk; } \\
{\text { Ca } a^{2+} \text {-PK; FAK; AAPK }}_{\text {Increased: JNK }}\end{array}$ \\
\hline Other & Decreased: MDRP; HSP-70 \\
\hline
\end{tabular}

${ }^{\star}$ Indicates effect documented in TNBC cells, [19]. cytokeratins 5, 6, 14, and 17, smooth muscle actin, P-cadherin and c-kit $[13,14]$. These molecular alterations have led to intensive research efforts to identify drug entities that will specifically target TNBC cancers. A summary of some of the possible therapies is included in Table 1 [14-17].

One promising area of research for cancer chemotherapies, especially for drug-resistant cells, is the plant phenols. A wide range of compounds are currently under development with several showing promise as they target multiple pathways to effect cellular death. One chemical within this class which is attracting increased research attention is curcumin.

\section{Curcumin as a chemotherapeutic}

Curcumin, obtained from the roots and rhizomes of the perennial plant Curcuma longa, is cytotoxic towards both ER+ and TNBC cells [18-20]. For example, curcumin inhibited the proliferation of ER-MDA-MB-468 and MDA-MB-231 cells, with $\mathrm{IC}_{50}$ values of 1 and $7.6 \mu \mathrm{M}$, respectively $[19,21]$. Results from Lai et al., (2012) suggest that curcumin preferentially targets cell lines lacking ER with SKBr3 and MDA-MB-231 (both ER-) cells being more sensitive to curcumin exposure than the ER+ lines BT474 or MCF7 $[19,20]$. Curcumin's mechanism of action appears to be multifaceted. Research has reported effects on inflammatory cytokines, growth factor receptors, metastatic and invasion markers, apoptosis related proteins and cell cycle proteins. A summary of these actions is provided in Table $2[22,23]$.

Curcumin induces apoptosis in most, if not all, breast cancer cell lines and this occurs via activation of the mitochondrialdependent apoptotic pathway [24]. In most cells, curcumin induces a loss of the mitochondrial membrane potential, opening of the transition pore, releasing cytochrome c, activating caspase- -9 and caspase- 3 and cleaving PARP, ultimately leading to DNA fragmentation and apoptosis [25] [26]. Down regulation of anti-apoptotic proteins ( $\mathrm{BCl}-2$ and $\mathrm{BCl}-\mathrm{XL}$ ) and up regulation of pro-apoptotic proteins (Bad and Bax) also leads to curcumin-induced apoptosis in many cancer cells including breast cancer [25]. Interestingly, many of these effects appear to be independent of the receptor status of the cell, with triple negative cell lines being similarly or more susceptible to curcumin than cell lines where the ER, PR or HER2 is present $[\mathbf{2 7}, \mathbf{1 1}]$.

Curcumin is also a potent inhibitor of angiogenesis inhibiting both VEGF and $\beta$-FGF expression in MDA-MB-231 cells at 50 $\mu$ M. Low doses of curcumin $(15 \mu \mathrm{M})$ inhibited the invasive potential of MDA-MB-231 cells by down regulation of MMP-2, MMP-3 and MMP-9 and up regulation of tissue inhibitor metalloproteinase (TIMP-1, 2) $[27,28]$. Curcumin (from $10 \mu \mathrm{M}$ ) inhibited integrin $a(6) \beta(4)$, a laminin adhesion receptor in MDA-MB-231 cells and thus inhibited cell motility and invasion [29]. Similarly, in an in vivo xenograft model, the administration of curcumin $(2 \% \mathrm{w} / \mathrm{w}$ in the diet) significantly decreased the incidence of breast cancer metastasisto the lung at five weeks. This was associated with suppression of the expression of NFKB, COX2 
and MMP-9 [30]. This finding was corroborated by a similar study where a lower dose ( $1 \% \mathrm{w} / \mathrm{w}$ in the diet) suppressed lung metastasis of breast cancer tumours after 21 days. Results showed that treatment with curcumin was associated with a decrease in NFKB, AP-1 and MMP-9 expression levels [31].

\section{Improving naturally derived compounds - combination studies}

The use of curcumin as a clinical drug is limited by poor bioavailability. Many groups have investigated whether combining curcumin with other existing or promising therapies may alleviate this problem. For example, a combination of the two naturally derived compounds curcumin and epigallocatechin gallate (EGCG) was effective in both in vitro and in vivo models of TNBC. In MDA-MB-231 cells these two compounds (EGCG at $25 \mu \mathrm{M}$ and curcumin at $3 \mu \mathrm{M}$ ) increased apoptotic cells and G2 arrest 2.6-fold compared to curcumin alone [32]. This effect was only observed in TNBC cells and not in MCF-7 cells. Importantly, this in vitro effect translated to tumour suppression in vivo. Specifically, curcumin $(200 \mathrm{mg} / \mathrm{kg})$ and EGCG (25 mg/kg) significantly suppressed MDA-MB-231 xenograft tumour volume by $49 \%$ compared to vehicle control after 10 weeks of treatment [32]. This was in part driven by a $78 \%$ decrease in VEGFR-1 protein expression in tumours.

Curcumin has also been reported to increase the sensitivity of various cancer cell lines to existing therapies such as doxorubicin [33], tamoxifen [34], cisplatin [33], camptothecin, daunorubicin, vincristine and melphalin [35]. Conversely, curcumin has also been reported to decrease the response of cells to camptothecin, doxorubicin and mechlorethamine [36]. The difference in results appears to be dose related with the latter study being conducted to mimic a dietary intake of curcumin (less than $1 \mu \mathrm{M}$ ) with the other studies testing a therapeutic scenario with curcumin concentrations at 10 $\mu \mathrm{M}$ or greater.

In breast cancer cells the combination of curcumin with paclitaxel in an MDA-MB-231 xenograft model, caused a significant reduction in tumour growth. Interestingly, the dose of paclitaxel was much lower $(7 \mathrm{mg} / \mathrm{kg}$ ) than previously reported as a single treatment [37]. Success has also been shown using in vitro combination studies. Specifically, when curcumin was combined with piperine the two drugs worked synergistically to inhibit breast cancer stem cell self-renewal without affecting normal cells [38]. Synergistic growth inhibition and the induction of apoptosis in MDA-MB-231 cells also occurred following the combination of curcumin and xanthorrhizol [39].

A recent phase II trial was designed to test the maximal tolerated dose of curcumin when co-administered in combination with docetaxel. While details were not provided, the researchers concluded that on-going investigation of the combination treatment was warranted suggesting some clinical gains over docetaxel administration alone [40]. The results from this study also demonstrated that the maximal tolerated dose of curcumin was $6000 \mathrm{mg} /$ day for seven days when given in combination with a standard docetaxel regime( 1 $h$ i.v. infusion every $3 w$ on $d 1$ for six cycles) [40].

\section{Novel drug delivery of natural compounds}

An alternative to combination therapy regimes is to utilize emerging nanotechnology-based drug delivery systems. Various structures such as nanoparticles, liposomes, micelles, adjuvants and phospholipid complexes have been developed in order to specifically target cancer cells in order to improve efficacy and bioavailability, while reducing toxicity [41]. Nanoparticles can improve the bio-distribution of drugs, as they are able to act as carriers of anti-cancer drugs by selectively using the unique pathophysiology of tumours, such as their enhanced vascular permeability and extensive angiogenesis. This improved efficacy can be demonstrated with gelatine nanoparticles which show increased accumulation within the tumour and prolonged in vivo circulation [42].

Curcumin loaded silk-fibroin nanoparticles $(<100 \mathrm{~nm})$ exhibited higher uptake, intracellular residence time and efficacy against HER2 positive MDA-MB-453 breast cancer cells [43]. Curcumin-oligo ethylene glycol (Cur-OEG) nanoparticles have also been studied for their anticancer effect in both in vitro and in vivo models of breast cancer. Curc-OEG nanoparticles showed in vitro antitumor activity towards several human cancer cells with an $\mathrm{IC}_{50}$ value of $1.4 \mu \mathrm{g} / \mathrm{ml}$ in MDA-MB-468 cells. Furthermore, intravenous injection of Curc-OEG nanoparticles $(25 \mathrm{mg} / \mathrm{kg})$ was non-toxic to the mice and exhibited improved bioavailability and significant tumour suppression after $48 \mathrm{~h}$ in an MDA-MB-468 xenograft model.

In an alternative system, curcumin was encapsulated in poly(lactic-co-glycolide) (PLGA). These loaded nanoparticles elicited asix-fold increase in curcumin uptake and increased cytotoxicity in MDA-MB-231 cells as compared to curcumin alone [44]. In vivo, a single dose of subcutaneously injected PLGA-particles sustained curcumin levels in the blood for 30 days with 1- to 30 fold increased curcumin concentrations detected in the lungs and brain compared to the blood [45]. Furthermore, curcumin $(58.2 \mathrm{mg} / \mathrm{mouse}$, injected $24 \mathrm{~h}$ prior to tumour inoculation) inhibited the growth of tumours in MDA-MB-231 xenografts by $49 \%$ compared to the mice treated with blank PLGA-particles or native curcumin (4.4mg,i.p.) [45]. The mechanisms of tumour reduction mirrored in vitro results with decreases in VEGF (decreased 78\% vs. control), MMP-9 (57\%), Ki67 (45\%) and Cyclin-D1 (52\%). Interestingly, repeated systemic dosing of curcumin had no effect on tumour growth or apoptosis markers. Therefore, the study concluded that sustained release microparticles of curcumin are more effective than repeated systemic injections of curcumin for breast cancer chemoprevention. A second in vivo study showed complementary results with curcumin nanoparticle formulation having a higher bioavailability and longer halflife in rats compared to free curcumin. Specifically, after intravenous administration of curcumin-nanoparticle ( 2.5 
Cridge et al. Oncology Discovery 2013,

http://www.hoajonline.com/journals/pdf/2052-6199-1-6.pdf

doi: 10.7243/2052-6199-1-6

$\mathrm{mg} / \mathrm{kg}$ ), the serum levels of curcumin after $24 \mathrm{~h}$ were more than double those in the non-nanoparticle treated rats [46]. In vitro results from this study also showed decreased protein levels of VEGF, MMP-9 and Cyclin-D1.

Multi-functional nanoparticles are also now under development. These layered systems are designed to maximize drug delivery; allow MRI, magnetic, or thermo-targeted activation; and enhance imaging capabilities [44]. Curcumin loaded magnetic nanoparticles had greater cellular uptake as compared to PGLA-based formulations and in MDA-MB-231 the observed $I C_{50}$ values of curcumin decreased from 18.8 to $11 \mu \mathrm{M}$. This was in spite of the observation that due to the sustained release of curcumin from the magnetic nanoparticle only $40 \%$ of the loaded drug had been released within the measurement timeframe. The authors suggest that the overall in vivo tumour suppressive effect would be significantly greater [44].

\section{Synthetic derivatives}

An alternative to encapsulation systems to enhance the bioavailability of curcumin is chemical alteration of the base structure to increase systemic uptake. The aim of these modifications is to produce a compound with greater stability, bioavailability and ultimately efficacy. The basic structure of curcumin is of two phenol groups connected by two $a, \beta$ unsaturated carbonyl groups (Table 3). The central diketones can form stable enols which are readily deprotonated to enolates. The equilibrium between the ketone, enol and enolate forms is responsible for the antioxidant properties of curcumin [47]. Modification of the phenolic rings and b-diketone moiety of curcumin has led to a range of different curcumin analogues with improved activities (Table 3) [48]. The first-generation curcumin derivatives exhibited enhanced activity and stability in biological medium compared to curcumin.

The curcumin analogues (FLLL 11 and FLLL 12) produced by exchanging the b-diketone moiety for an ab unsaturated ketone, exhibited more potent antitumor activity than curcumin in various ER+ and ER- human breast cancer cells [49]. The IC ${ }_{50}$ values for FLLL11 and FLLL12 ranged from 0.3 to $5.7 \mu \mathrm{M}$, significantly lower than curcumin in equivalent cell lines. Both the analogues inhibited STAT3, Akt and HER2/ Neu pathways and induced apoptosis at concentrations of $10 \mu \mathrm{M}$. The apoptosis was mediated via activation of cleaved PARP and caspase 3. These analogues were also effective in combination with doxorubicin as they exhibited a synergistic anti-proliferative effect in MDA-MB-231 breast cancer cells. In addition, the compounds inhibited anchorage independent growth and cell migration in MDA-MB-231 cells [49].

The evidence from FLLL11 and FLLL12 suggests that incorporating one or more pairs of methoxy groups is key to increasing cytotoxicity. Ohori et al., (2006), screened over 50 curcumin derivatives [50]. The most potent were GOYO35 and GOYO30, which incorporated multiple methoxy groups at either end of the compound. In MDA-MB-231 cells GOYO30 has a reported $\mathrm{IC}_{50}$ of $1.2 \mu \mathrm{M}$ [51], significantly less than curcumin. Compound $15 \mathrm{H}$ with a combination of methoxy additions and pentone ring incorporation showed an $\mathrm{IC}_{50}$ of $1.9 \mu \mathrm{M}$ in MCF7 cells, the lowest reported value in these ER+ cells to date [52]. Fuchs et al., (2009), conducted a screen of twenty four compounds. Of thoseanalysed GOYO21, with three methoxy pairs, was the most potent. GOYO21 (also reported as compound 23) showed toxicity at sub-micromolar concentrations in MDA-MB-231 cells $(0.6 \mu \mathrm{M})$ [53]. The major screening study conducted by Ohori et al., (2006), identified three key features of potent cytotoxic derivatives: 1 ) a 5 -carbon vs. 7-carbon tether in the central portion of the molecule; 2 ) the importance of the methoxy residues; and 3) maintenance of the enone/ketone moiety [50]. However, the importance of the enone group is disputed. Previously, Ishida et al., found that converting the enone to a pyrazole group resulted in the most potent compound in their screen of thirty two curcuminderivatives. The resulting chemical, labelled compound 4 was only tested in MCF-7 cells where it had a reported $I C_{50}$ value of $3.9 \mu \mathrm{M}$ [54].

Second generation curcumin derivatives have focused on the importance of the central structure and are based on the inclusion of a heterocyclic or piperidine ring in place of the ketone moiety. This imparts a rigid confirmation that has led to a broad spectrum of antitumor activity. The second generation curcumin derivative 2,6-bis ((3- methoxy-4hydroxyphenyl) methylene)-cyclohexanone (BMHPC) was cytotoxic toward ER- breast cancer cells $\left(\mathrm{IC}_{50}\right.$ of $\left.5.0 \mu \mathrm{M}\right)$ and displayed anti-angiogenic properties in human and murine endothelial cell lines $[18,21,49,50,52-59]$.

Two further analogues, 2,6-bis(pyridin-3-ylmethylene)cyclohexanone (RL90) and 2,6-bis(pyridin-4-ylmethylene)cyclohexanone (RL91) (Table 3) also showed increased cytotoxicity towards ER- breast cancer cells (MDA-MB-231, $\mathrm{SKBr} 3$ ). Interestingly, removing the phenolic side groups and replacing them with piperidine rings increased cytotoxicity towards breast cancer cells markedly $\left(\mathrm{IC}_{50}\right.$ of 0.51 and 0.23 $\mu \mathrm{M}$, respectively) [56]. Both RL90 and RL91 modulated the expression of variety of cell signalling proteins such as EGFR, Akt, HER2, $\beta$-catenin and NFKB [56]. Treatment with RL90 and RL91 also showed activation of stress kinases, as evidenced by phosphorylation of both JNK $1 / 2$ and p38 MAPK. Furthermore, RL90 and RL91 produced cell cycle arrest at G2/M phase in MDA-MB-231 and SKBr3 cells. Specifically, treatment of MDAMB-231 cells with RL90 ( $3 \mu \mathrm{M})$ or RL91 $(2.5 \mu \mathrm{M})$ significantly increased the proportion of cells in G2/M phase by 52 and $49 \%$ compared to control, respectively. RL90 and RL91 also increased the proportion of apoptotic cells by $164 \%$ and $406 \%$ of control, respectively [56].

Compound, 8 and 18 (Table 3 ) bearing the n-alkyl piperidone group showed potent cytotoxic activity towards various breast cancer cells [57]. This structure was recently further modified by replacing the methylene groups and the two 
Cridge et al. Oncology Discovery 2013,

http://www.hoajonline.com/journals/pdf/2052-6199-1-6.pdf

Table 3. Chemical structures of curcumin derivatives and their relative in vitro potency.

$\left(\mathrm{NR}^{\star}\right.$ - Not reported)

\begin{tabular}{|c|c|c|c|c|}
\hline $\begin{array}{l}\text { Compound } \\
\text { Name }\end{array}$ & Structure & Cell line & IC $50(\mu \mathrm{M})$ & Ref \\
\hline Curcumin & & $\begin{array}{l}\text { MDA-MB-231 } \\
\text { MDA-MB-468 }\end{array}$ & $\begin{array}{l}7.6 \\
1\end{array}$ & $\begin{array}{c}16 \mathrm{a} \\
17\end{array}$ \\
\hline \multicolumn{5}{|c|}{ First Generation Derivatives } \\
\hline FLLL11 & 0 & $\begin{array}{l}\text { MCF-7 } \\
\text { MDA-MB-231 } \\
\text { MDA-MB-468 } \\
\text { MDA-MB-453 } \\
\text { SKBr3 }\end{array}$ & $\begin{array}{l}2.4 \\
2.8 \\
0.3 \\
4.7 \\
5.7\end{array}$ & 44 \\
\hline FLLL12 & 0 & $\begin{array}{l}\text { MCF-7 } \\
\text { MDA-MB-231 } \\
\text { MDA-MB-468 } \\
\text { MDA-MB-453 } \\
\text { SKBr3 }\end{array}$ & $\begin{array}{l}1.7 \\
2.7 \\
0.3 \\
1.3 \\
3.8\end{array}$ & 44 \\
\hline GO-YO30 & & MDA-MB-231 & 1.2 & 45 \\
\hline $15 \mathrm{H}$ & & MCF7 & 1.9 & 47 \\
\hline $\begin{array}{l}\text { Compound } 23 \\
\text { (GOYO21) }\end{array}$ & & $\begin{array}{l}\text { MCF-7 } \\
\text { MDA-MB-231 }\end{array}$ & $\begin{array}{l}2.4 \\
0.6\end{array}$ & 48 \\
\hline Compound 4 & & MCF-7 & 3.9 & 49 \\
\hline
\end{tabular}

Second Generation Derivatives

BMHPC<smiles>COc1cc(/C=C2\CCC/C(=C\c3ccc(O)c(O)c3)C2=O)ccc1O</smiles>

RL90<smiles>O=C1/C(=C/c2cccnc2)CCC/C1=C\c1cccnc1</smiles>

MDA-MB-231

1.54 SKBr3

RL91<smiles>O=C1/C(=C/c2ccncc2)CCC/C1=C\c1ccncc1</smiles>

MDA-MB-231<smiles>COc1cc(/C=C/C=C2\CC[C@H](C)/C(=C\C=C\c3cc(C)c(O)c(O)c3)C2=O)cc(C)c1O</smiles> 
Cridge et al. Oncology Discovery 2013,

http://www.hoajonline.com/journals/pdf/2052-6199-1-6.pdf

Continuation of Table 3

\begin{tabular}{|c|c|c|c|c|}
\hline $\begin{array}{l}\text { Compound } \\
\text { Name }\end{array}$ & Structure & Cell line & IC $50(\mu \mathrm{M})$ & Ref \\
\hline Compound 8 & $\mathrm{CH}_{3}$ & $\begin{array}{l}\text { MCF-7 } \\
\text { MDA-MB-31 } \\
\text { MDA-MB-435 } \\
\text { HS-578T } \\
\text { BT-549 } \\
\text { T-47D }\end{array}$ & $\begin{array}{l}2.3 \\
17.9 \\
6.8 \\
5.4 \\
32.8 \\
15.1\end{array}$ & 52 \\
\hline PAC & $\mathrm{CH}_{3}$ & $\begin{array}{l}\text { BEC114 } \\
\text { MDA-MB-231 } \\
\text { MCF7 } \\
\text { T47D }\end{array}$ & $\begin{array}{l}\mathrm{NR}^{*} \\
\mathrm{NR}^{*} \\
\mathrm{NR}^{*} \\
\mathrm{NR}^{*}\end{array}$ & 53 \\
\hline $\mathrm{EF}-24$ & $\mathrm{O}$ & MDA-MB-231 & 0.8 & 54 \\
\hline RL66 & $\mathrm{CH}_{3}$ & $\begin{array}{l}\text { MDA-MB-231 } \\
\text { MDA-MB-468 } \\
\text { SKBr3 }\end{array}$ & $\begin{array}{l}0.8 \\
0.5 \\
0.6\end{array}$ & $15 a$ \\
\hline RL71 & $\mathrm{CH}_{3}$ & $\begin{array}{l}\text { MDA-MB-231 } \\
\text { MDA-MB-468 } \\
\text { SKBr3 }\end{array}$ & $\begin{array}{l}0.3 \\
0.3 \\
0.4\end{array}$ & $15 \mathrm{a}$ \\
\hline
\end{tabular}

carbonyl groups in curcumin by $\mathrm{N}$-methyl-4 piperidone. The resulting compound 5-bis (4-hydroxy-3- methoxybenzylidene)$\mathrm{N}$ - methyl-4-piperidone (PAC) (Table 3 ) was 5 times more effective than curcumin in inducing apoptosis in ER- breast cancer cells (MDA-MB-231, BEC114) [58]. Additionally, the proapoptotic effect was 10 times higher against these ER- breast cancer cells than against ER+ cells (MCF-7, T-47D). In vivo, PAC (100 mg/kg/day) suppressed the growth of MDA-MB-231 xenografts [58]. Importantly, the solubility of PAC was 27-fold higher than curcumin and $1 \mathrm{~h}$ after the injection, the levels of ${ }^{18} \mathrm{~F}$-PAC in the blood was 5 -fold higher than the levels ${ }^{18} \mathrm{~F}$-curcumin. These studies suggested better pharmacokinetics and tissue bio-distribution of PAC compared to curcumin in mice [58]. Cell cycle analysis revealed that PAC $(10 \mu \mathrm{M})$ treatment of MDA-MB-231 cells increased the proportion of cells undergoing G2/M phase arrest and induced apoptosis in $55 \%$ of MDA-MB-231 cells [58]. PAC down regulated the expression of NFkB, surviving and its downstream effectors cyclin $\mathrm{D} 1$ and $\mathrm{BCl}-2$ and subsequently showed up-regulation of $\mathrm{p} 21^{\text {WAF1 } 1}$ expression both in vitro and in vivo.

Several fluorinated derivatives have also been synthesized. Of these, EF-24 exhibited potent cytotoxicity toward MDAMB-231 cells ( $\left(\mathrm{C}_{50}\right.$ of $\left.0.8 \mu \mathrm{M}\right)[59]$ and induced breast tumour regression in athymic nude mice. Specifically, tumour weight following $20 \mathrm{mg} / \mathrm{kg}$ was decreased by approximately $30 \%$ compared to control, whereas $100 \mathrm{mg} / \mathrm{kg}$ decreased tumour weight by $55 \%$. Interestingly, no toxicity was observed at a dose of $100 \mathrm{mg} / \mathrm{kg}$, which was well below the maximum tolerated dose (MTD) of $200 \mathrm{mg} / \mathrm{kg}$ [59]. Mechanistic studies of EF-24 were also performed in MDA-MB-231 cells. Results show cell cycle arrest in the G2/M phase and increased intracellular ROS levels after 48 hours [59]. Further mechanistic studies demonstrated that EF-24 inhibited the pro-angiogenic transcription factor, HIF-1a at the post-transcriptional level by a VHL-dependent but proteasome-independent mechanism in MDA-MB-231 cells [60]. Using coagulation factor VIla (fVIla) as a carrier to target delivery to the tissue factor (TF), EF-24 significantly decreased the viability of the TF-expressing MDA-MB-231 and HUVEC cells in a concentration dependent manner. Furthermore, the administration of 5 intravenous injections of the EF-24-FFRck-fVIla conjugate (containing 50 $\mu \mathrm{M}$ of EF-24) for two weeks significantly reduced the tumour size in MDA-MB-231 breast cancer xenografts. The tumour cells also showed activation of caspase 3, a marker of apoptosis [61]. This suggests that it has potent anti-angiogenic and anti-cancer activity in breast cancer cells. 
Cridge et al. Oncology Discovery 2013,

http://www.hoajonline.com/journals/pdf/2052-6199-1-6.pdf

doi: 10.7243/2052-6199-1-6

Yadav et al., (2010) examined 18 second generation curcuminanalogues. Of these two compounds showed potent cytotoxicity: 3,5-bis (pyridine-4-yl)-1-methylpiperidin4-one (RL66) and; 3,5-bis (3,4,5-trimethoxybenzylidene)1-methylpiperidin-4-one (RL71) (Table 3). Both had IC values below $1 \mathrm{mM}$ in oestrogen receptor negative cell lines (MBA-MB-231 and MDA-MB-468) [18]. RL66 at $2 \mu$ M caused cell cycle arrest, a decrease in HER-2/neu phosphorylation, increased p27 levels, caspase 3 cleavage and apoptosis in $\mathrm{SKBr} 3$ cells after $48 \mathrm{~h}$ [62]. Furthermore, in MDA-MB468 cells RL66 (2 $\mu \mathrm{M})$ decreased Akt phosphorylation and transiently increased JNK1/2 and MAPK p38 phosphorylation. Cell migration in HUVEC cells was inhibited by $46 \%$ indicating that RL66 is anti-angiogenic [62]. In vivo, RL66 (8.5 mg/ $\mathrm{kg}$ orally) decreased the growth of MDA-MB-468 cell xenografts over a 10 week treatment period [62]. Additionally, microvessel density in the tumors was decreased by $57 \%$ as compared to control. Based on these results the authors generated a structure with the central piperidine ring and added the methoxy groups identified from the stage one investigations. The resulting compound, $\mathrm{RL} 71$, is the most potent curcumin derivative developed to date. In vitro results show that ithas consistent cytotoxicity across breast (ER-) [18], (ER+ and tamoxifen-resistant) (Leung personal communication), prostate (Mazumder personal communication), colon [63] and leukemia cell lines [18]. Similar to RL66 and the parent compound curcumin it has a broad mechanism of action includinginhibition of EGFR, Akt, NFKB, mTOR and Her- ${ }^{61}$. RL71 has also shown potent efficacy in a range of migration and invasion models of metastasis. Specifically, $1 \mu \mathrm{M}$ of RL71 significantly inhibited HUVEC cell migration by $46 \%$ compared to vehicle control and completely inhibited endothelial tube formation [64]. Furthermore, in MDA-MB-231 cells $1 \mu \mathrm{M}$ RL71 significantly reduced cell migration into a scratch area after $24 \mathrm{~h}$ [64].

Overall, curcumin is an exciting potential chemotherapeutic. While the parent compound has been shown to have cancerspecific toxicity and a range of target mechanisms, its use is limited by poor bioavailability. However, a range of new technologies means that this drug may be able to be adapted for clinical use. Specifically, by using encapsulation techniques such as micelles, targeted delivery can be achieved. These systems show a great deal of promise in pre-clinical studies with curcumin micelles being highly cytotoxic in a range of in vivo assays. Alternatively, the synthesis of derivatives such as RL71 demonstrates that the cytotoxicity of curcumin can be retained, or even improved, while increasing the absorption across the gut lumen. Mechanistic studies show that the mechanism of action for curcumin and the derivatives is broad meaning that they show potential in currently untreatable cancers. For patients with triple negative breast cancer, where current therapies show little efficacy and the need for new therapies is imperative, these potent derivatives have the potential to form the basis for a new effective treatment.

\section{Competing interests}

The authors declare that they have no competing interests.

Authors' contributions

\begin{tabular}{|l|c|c|c|}
\hline Authors' contributions & BJC & LL & RJR \\
\hline Research concept and design & -- & $\sqrt{ }$ & $\sqrt{ }$ \\
\hline Collection and/or assembly of data & $\sqrt{ }$ & -- & -- \\
\hline Data analysis and interpretation & $\sqrt{ }$ & -- & -- \\
\hline Writing the article & $\sqrt{ }$ & -- & -- \\
\hline Critical revision of the article & -- & -- & $\sqrt{ }$ \\
\hline Final approval of article & -- & $\sqrt{ }$ & $\sqrt{ }$ \\
\hline Statistical analysis & -- & -- & -- \\
\hline
\end{tabular}

Acknowledgement

The authors also thank Rachinda J. Brasender

for her editorial assistance.

Publication history

Editor: Dmitry Pshezhetskiy, University of East Anglia, UK. EIC: Paul J. Higgins, Albany Medical College, USA.

GJ Peters, VU University Medical Center, Netherlands.

William Chi-shing Cho, Queen Elizabeth Hospital, Hong Kong.

Received: 22-Jul-2013 Revised: 02-Aug-2013

Accepted: 09-Aug-2013 Published: 18-Sep-2013

\section{References}

1. Bertos NR and Park M. Breast cancer - one term, many entities? J Clin Invest. 2011; 121:3789-96. | Article | PubMed Abstract | PubMed Full Text

2. Weigelt B, Horlings HM, Kreike B, Hayes MM, Hauptmann M, Wessels LF, de Jong D, Van de Vijver MJ, Van't Veer LJ and Peterse JL. Refinement of breast cancer classification by molecular characterization of histological special types. J Pathol. 2008; 216:141-50. | Article | PubMed

3. DeSantis C, Siegel R, Bandi $P$ and Jemal A. Breast cancer statistics, 2011. CA Cancer J Clin. 2011; 61:409-18. | Article | PubMed

4. Mackay A, Weigelt B, Grigoriadis A, Kreike B, Natrajan R, A'Hern R, Tan DS, Dowsett M, Ashworth A and Reis-Filho JS. Microarray-based class discovery for molecular classification of breast cancer: analysis of interobserver agreement. J Nat/ Cancer Inst. 2011; 103:662-73. | Article | PubMed Abstract | PubMed Full Text

5. Polyak K. Heterogeneity in breast cancer. J Clin Invest. 2011; 121:3786-8. | Article | PubMed Abstract | PubMed Full Text

6. Prat A and Perou CM. WITHDRAWN: Deconstructing the molecular portraits of breast cancer. Mol Oncol. 2010. | Article | PubMed

7. Weigelt B, Mackay A, A'Hern R, Natrajan R, Tan DS, Dowsett M, Ashworth $A$ and Reis-Filho JS. Breast cancer molecular profiling with single sample predictors: a retrospective analysis. Lancet Oncol. 2010; 11:339-49. | Article I PubMed

8. Reis-Filho JS and Tutt AN. Triple negative tumours: a critical review. Histopathology. 2008; 52:108-18. | Article | PubMed

9. Chen JQ and Russo J. ERalpha-negative and triple negative breast cancer: molecular features and potential therapeutic approaches. Biochim Biophys Acta. 2009; 1796:162-75. | Article | PubMed Abstract | PubMed Full Text

10. Conte, P. and V. Guarneri. Triple-negative breast cancer: current management and future options. European Journal of Cancer Supplements. 2009; 7:14-18. | Article

11. Rowe DL, Ozbay T, O'Regan RM and Nahta R. Modulation of the BRCA1 Protein and Induction of Apoptosis in Triple Negative Breast Cancer Cell Lines by the Polyphenolic Compound Curcumin. Breast Cancer (Auckl). 
Cridge et al. Oncology Discovery 2013,

http://www.hoajonline.com/journals/pdf/2052-6199-1-6.pdf

doi: 10.7243/2052-6199-1-6

2009; 3:61-75. | Article | PubMed Abstract | PubMed Full Text

12. Arslan C, Dizdar $O$ and Altundag K. Pharmacotherapy of triple-negative breast cancer. Expert Opin Pharmacother. 2009; 10:2081-93. | Article | PubMed

13. Venkitaraman R. Triple-negative/basal-like breast cancer: clinical, pathologic and molecular features. Expert Rev Anticancer Ther. 2010; 10:199-207. | Article | PubMed

14. Irvin, W.J., Jr. and L.A. Carey. What is triple-negative breast cancer? European Journal of Cancer, 2008. 44(18): p. 2799-805. | Article

15. Dawson SJ, Provenzano E and Caldas C. Triple negative breast cancers: clinical and prognostic implications. Eur J Cancer. 2009; 45 Suppl 1:2740. | Article | PubMed

16. Cleator S, Heller W and Coombes RC. Triple-negative breast cancer: therapeutic options. Lancet Oncol. 2007; 8:235-44. | Article | PubMed

17. Hudis CA and Gianni L. Triple-negative breast cancer: an unmet medical need. Oncologist. 2011; 16 Suppl 1:1-11. | Article | PubMed

18. Yadav B, Taurin S, Rosengren RJ, Schumacher M, Diederich M, SomersEdgar TJ and Larsen L. Synthesis and cytotoxic potential of heterocyclic cyclohexanone analogues of curcumin. Bioorg Med Chem. 2010; 18:6701-7. | Article | PubMed

19. Lai HW, Chien SY, Kuo SJ, Tseng LM, Lin HY, Chi CW and Chen DR. The Potential Utility of Curcumin in the Treatment of HER-2-Overexpressed Breast Cancer: An In Vitro and In Vivo Comparison Study with Herceptin. Evid Based Complement Alternat Med. 2012; 2012:486568. Article I PubMed Abstract I PubMed Full Text

20. Verma SP, Salamone E and Goldin B. Curcumin and genistein, plant natural products, show synergistic inhibitory effects on the growth of human breast cancer MCF-7 cells induced by estrogenic pesticides. Biochem Biophys Res Commun. 1997; 233:692-6. | Article | PubMed

21. Squires MS, Hudson EA, Howells L, Sale S, Houghton CE, Jones JL, Fox LH, Dickens M, Prigent SA and Manson MM. Relevance of mitogen activated protein kinase (MAPK) and phosphotidylinositol-3-kinase/protein kinase B (PI3K/PKB) pathways to induction of apoptosis by curcumin in breast cells. Biochem Pharmacol. 2003; 65:361-76. | Article | PubMed

22. Dzeyk, J., B. Yadav, and R.J. Rosengren. Experimental Therapeutics for the Treatment of Triple Negative Breast Cancer. | Article

23. Shishodia S. Molecular mechanisms of curcumin action: gene expression. Biofactors. 2013; 39:37-55. | Article | PubMed

24. Karunagaran D, Rashmi R and Kumar TR. Induction of apoptosis by curcumin and its implications for cancer therapy. Curr Cancer Drug Targets. 2005; 5:117-29. | Article | PubMed

25. Ravindran J, Prasad $S$ and Aggarwal BB. Curcumin and cancer cells: how many ways can curry kill tumor cells selectively? AAPS J. 2009; 11:495510. | Article | PubMed Abstract | PubMed Full Text

26. Aggarwal BB, Kumar A and Bharti AC. Anticancer potential of curcumin: preclinical and clinical studies. Anticancer Res. 2003; 23:363-98. | PubMed

27. Shao ZM, Shen ZZ, Liu CH, Sartippour MR, Go VL, Heber D and Nguyen $M$. Curcumin exerts multiple suppressive effects on human breast carcinoma cells. Int I Cancer. 2002; 98:234-40. | Article | PubMed

28. Boonrao M, Yodkeeree S, Ampasavate C, Anuchapreeda S and Limtrakul $P$. The inhibitory effect of turmeric curcuminoids on matrix metalloproteinase-3 secretion in human invasive breast carcinoma cells. Arch Pharm Res. 2010; 33:989-98. | Article | PubMed

29. Kim HI, Huang H, Cheepala S, Huang S and Chung J. Curcumin inhibition of integrin (alpha6beta4)-dependent breast cancer cell motility and invasion. Cancer Prev Res (Phila). 2008; 1:385-91. | Article | PubMed

30. Aggarwal BB, Shishodia S, Takada Y, Banerjee S, Newman RA, BuesoRamos CE and Price JE. Curcumin suppresses the paclitaxel-induced nuclear factor-kappaB pathway in breast cancer cells and inhibits lung metastasis of human breast cancer in nude mice. Clin Cancer Res. 2005; 11:7490-8. | Article | PubMed

31. Bachmeier B, Nerlich AG, lancu CM, Cilli M, Schleicher E, Vene R, Dell'Eva $R$, Jochum $M$, Albini $A$ and Pfeffer $U$. The chemopreventive polyphenol Curcumin prevents hematogenous breast cancer metastases in immunodeficient mice. Cell Physiol Biochem. 2007; 19:137-52. | Article I PubMed
32. Somers-Edgar TJ, Scandlyn MJ, Stuart EC, Le Nedelec MJ, Valentine SP and Rosengren RJ. The combination of epigallocatechin gallate and curcumin suppresses ER alpha-breast cancer cell growth in vitro and in vivo. Int J Cancer. 2008; 122:1966-71. | Article | PubMed

33. Notarbartolo M, Poma P, Perri D, Dusonchet L, Cervello M and D'Alessandro N. Antitumor effects of curcumin, alone or in combination with cisplatin or doxorubicin, on human hepatic cancer cells. Analysis of their possible relationship to changes in NF-kB activation levels and in IAP gene expression. Cancer Lett. 2005; 224:53-65. | Article | PubMed

34. M. De Gasperi D. Cavazos and L. deGraffenried. Curcumin modulates tamoxifen response in resistant breast cancer cells. Cancer Research. 2009; 69:p. Abstract nr 3098. | Article

35. Bharti AC, Donato N, Singh S and Aggarwal BB. Curcumin (diferuloylmethane) down-regulates the constitutive activation of nuclear factor-kappa B and IkappaBalpha kinase in human multiple myeloma cells, leading to suppression of proliferation and induction of apoptosis. Blood. 2003; 101:1053-62. | Article | PubMed

36. Somasundaram S, Edmund NA, Moore DT, Small GW, Shi YY and Orlowski RZ. Dietary curcumin inhibits chemotherapy-induced apoptosis in models of human breast cancer. Cancer Res. 2002; 62:3868-75. | Article I PubMed

37. Kang HJ, Lee SH, Price JE and Kim LS. Curcumin suppresses the paclitaxel-induced nuclear factor-kappaB in breast cancer cells and potentiates the growth inhibitory effect of paclitaxel in a breast cancer nude mice model. Breast J. 2009; 15:223-9. | Article | PubMed

38. Kakarala M, Brenner DE, Korkaya H, Cheng C, Tazi K, Ginestier C, Liu S, Dontu $\mathrm{G}$ and Wicha MS. Targeting breast stem cells with the cancer preventive compounds curcumin and piperine. Breast Cancer Res Treat. 2010; 122:777-85. | Article | PubMed Abstract | PubMed Full Text

39. Cheah YH, Nordin FJ, Sarip R, Tee TT, Azimahtol HL, Sirat HM, Rashid BA, Abdullah NR and Ismail Z. Combined xanthorrhizol-curcumin exhibits synergistic growth inhibitory activity via apoptosis induction in human breast cancer cells MDA-MB-231. Cancer Cell Int. 2009; 9:1. | Article | PubMed Abstract | PubMed Full Text

40. Bayet-Robert M, Kwiatkowski F, Leheurteur M, Gachon F, Planchat E, Abrial C, Mouret-Reynier MA, Durando X, Barthomeuf C and Chollet P. Phase I dose escalation trial of docetaxel plus curcumin in patients with advanced and metastatic breast cancer. Cancer Biol Ther. 2010; 9:8-14. | Article | PubMed

41. Anand P, Thomas SG, Kunnumakkara AB, Sundaram C, Harikumar KB, Sung B, Tharakan ST, Misra K, Priyadarsini IK, Rajasekharan KN and Aggarwal BB. Biological activities of curcumin and its analogues (Congeners) made by man and Mother Nature. Biochem Pharmacol. 2008; 76:1590-611. | Article | PubMed

42. van Vlerken LE, Vyas TK and Amiji MM. Poly(ethylene glycol)-modified nanocarriers for tumor-targeted and intracellular delivery. Pharm Res. 2007; 24:1405-14. | Article | PubMed

43. Gupta V, Aseh A, Rios CN, Aggarwal BB and Mathur AB. Fabrication and characterization of silk fibroin-derived curcumin nanoparticles for cancer therapy. Int J Nanomedicine. 2009; 4:115-22. | Article | PubMed Abstract | PubMed Full Text

44. Yallapu MM, Gupta BK, Jaggi M and Chauhan SC. Fabrication of curcumin encapsulated PLGA nanoparticles for improved therapeutic effects in metastatic cancer cells. J Colloid Interface Sci. 2010; 351:19-29. | Article I PubMed

45. Shahani K, Swaminathan SK, Freeman D, Blum A, Ma L and Panyam J. Injectable sustained release microparticles of curcumin: a new concept for cancer chemoprevention. Cancer Res. 2010; 70:4443-52. | Article | PubMed Abstract | PubMed Full Text

46. Anand P, Nair HB, Sung B, Kunnumakkara AB, Yadav VR, Tekmal RR and Aggarwal BB. Design of curcumin-loaded PLGA nanoparticles formulation with enhanced cellular uptake, and increased bioactivity in vitro and superior bioavailability in vivo. Biochem Pharmacol. 2010; 79:330-8. | Article | PubMed Abstract | PubMed Full Text

47. Jovanovic, S.V.S., S.; Boone, C. W.; Simic, M. G., H-atom transfer is a preferred antioxidant mechanism of curcumin. J. Am. Chem. Soc., 1999. 121: p. 9677-9681. | Article

48. Mosley CA, Liotta DC and Snyder JP. Highly active anticancer curcumin 
Cridge et al. Oncology Discovery 2013,

http://www.hoajonline.com/journals/pdf/2052-6199-1-6.pdf

doi: $10.7243 / 2052-6199-1-6$

analogues. Adv Exp Med Biol. 2007; 595:77-103. | Article | PubMed

49. Lin L, Hutzen B, Ball S, Foust E, Sobo M, Deangelis S, Pandit B, Friedman L, Li C, Li PK, Fuchs J and Lin J. New curcumin analogues exhibit enhanced growth-suppressive activity and inhibit AKT and signal transducer and activator of transcription 3 phosphorylation in breast and prostate cancer cells. Cancer Sci. 2009; 100:1719-27. | Article | PubMed

50. Ohori H, Yamakoshi H, Tomizawa M, Shibuya M, Kakudo Y, Takahashi A, Takahashi S, Kato S, Suzuki T, Ishioka C, Iwabuchi Y and Shibata H. Synthesis and biological analysis of new curcumin analogues bearing an enhanced potential for the medicinal treatment of cancer. Mol Cancer Ther. 2006; 5:2563-71. | Article | PubMed

Citation:

Cridge BJ, Larsen L and Rosengren RJ. Curcumin and its derivatives in breast cancer: Current developments and potential for the treatment of drug-resistant cancers. Oncol Discov. 2013; 1:6. http://dx.doi.org/10.7243/2052-6199-1-6

51. Hutzen B, Friedman L, Sobo M, Lin L, Cen L, De Angelis S, Yamakoshi H, Shibata H, Iwabuchi $Y$ and Lin J. Curcumin analogue GO-Y030 inhibits STAT3 activity and cell growth in breast and pancreatic carcinomas. Int $J$ Oncol. 2009; 35:867-72. | Article | PubMed

52. Woo HB, Eom YW, Park KS, Ham J, Ahn CM and Lee S. Synthesis of substituted benzimidazolyl curcumin mimics and their anticancer activity. Bioorg Med Chem Lett. 2012; 22:933-6. | Article | PubMed

53. Fuchs JR, Pandit B, Bhasin D, Etter JP, Regan N, Abdelhamid D, Li C, Lin J and Li PK. Structure-activity relationship studies of curcumin analogues. Bioorg Med Chem Lett. 2009; 19:2065-9. | Article | PubMed

54. Ishida J, Ohtsu H, Tachibana Y, Nakanishi Y, Bastow KF, Nagai M, Wang $\mathrm{HK}$, Itokawa $\mathrm{H}$ and Lee KH. Antitumor agents. Part 214: synthesis and evaluation of curcumin analogues as cytotoxic agents. Bioorg Med Chem. 2002; 10:3481-7. | Article | PubMed

55. Adams BK, Ferstl EM, Davis MC, Herold M, Kurtkaya S, Camalier RF, Hollingshead MG, Kaur G, Sausville EA, Rickles FR, Snyder JP, Liotta DC and Shoji M. Synthesis and biological evaluation of novel curcumin analogs as anti-cancer and anti-angiogenesis agents. Bioorg Med Chem. 2004; 12:3871-83. | Article | PubMed

56. Somers-Edgar TJ, Taurin S, Larsen L, Chandramouli A, Nelson MA and Rosengren RJ. Mechanisms for the activity of heterocyclic cyclohexanone curcumin derivatives in estrogen receptor negative human breast cancer cell lines. Invest New Drugs. 2011; 29:87-97. | Article | PubMed

57. Youssef, K.M. and M.A. El-Sherbeny. Synthesis and antitumor activity of some curcumin analogs. Archiv der Pharmazie (Weinheim), 2005. 338(4): p. 181-9. | Article

58. Al-Hujaily EM, Mohamed AG, Al-Sharif I, Youssef KM, Manogaran PS, Al-Otaibi B, Al-Haza'a A, Al-Jammaz I, Al-Hussein K and Aboussekhra A. $P A C$, a novel curcumin analogue, has anti-breast cancer properties with higher efficiency on ER-negative cells. Breast Cancer Res Treat. 2011; 128:97-107. | Article | PubMed

59. Adams BK, Cai J, Armstrong J, Herold M, Lu YJ, Sun A, Snyder JP, Liotta DC, Jones DP and Shoji M. EF24, a novel synthetic curcumin analog, induces apoptosis in cancer cells via a redox-dependent mechanism. Anticancer Drugs. 2005; 16:263-75. | Article | PubMed

60. Thomas SL, Zhong D, Zhou W, Malik S, Liotta D, Snyder JP, Hamel E and Giannakakou P. EF24, a novel curcumin analog, disrupts the microtubule cytoskeleton and inhibits HIF-1. Cell Cycle. 2008; 7:2409-17. | Article | PubMed Abstract | PubMed Full Text

61. Shoji M, Sun A, Kisiel W, Lu YJ, Shim H, McCarey BE, Nichols C, Parker ET, Pohl J, Mosley CA, Alizadeh AR, Liotta DC and Snyder JP. Targeting tissue factor-expressing tumor angiogenesis and tumors with EF24 conjugated to factor VIla. J Drug Target. 2008; 16:185-97. | Article | PubMed

62. Yadav B, Taurin S, Larsen L and Rosengren RJ. RL66 a second-generation curcumin analog has potent in vivo and in vitro anticancer activity in ERnegative breast cancer models. Int J Oncol. 2012; 41:1723-32. | Article | PubMed

63. Gandhy, S.K., K.; Larsen, L.; Rosengren, R.; Safe, S., Curcumin-induced reactive oxygen species decreases specificity protein (SP) transcription factors by targeting microRNAs. BMC Cancer, 2012. 12: p. 564. | Article

64. Yadav B, Taurin S, Larsen L and Rosengren RJ. RL71, a second-generation curcumin analog, induces apoptosis and downregulates Akt in ERnegative breast cancer cells. Int J Oncol. 2012; 41:1119-27. | Article | PubMed 